\title{
Pleural Malignant Mesothelioma Clinical Distant Metastasis TNM Finding v8
}

National Cancer Institute

\section{Source}

National Cancer Institute. Pleural Malignant Mesothelioma Clinical Distant Metastasis

TNM Finding v8. NCI Thesaurus. Code C136381.

A clinical finding about one or more characteristics of pleural malignant mesothelioma, following the rules of the TNM AJCC v8 classification system as they pertain to distant metastases. 